\title{
A SURVEY ON THE BEETLE DIVERSITY OF LUMDING
}

\section{JASHODEB ARJUN \& RAJESH PAUL}

Zoology Department, Lumbding College, Lumbding, 782447, Assam, India

\begin{abstract}
Insects dominate every major terrestrial biomass, out of which the order Coleoptera has the richest species diversity. Assam is undoubtedly the adobe of many flora and fauna. Lumding, a small part of Hojai district, Assam is a railway based town with rich reserve forests which are heavily populated with different types of plants, birds, insects and other lower and higher animals. In our previous works on Lumding, we have procured that this place is richly populated with different species of insects which motivated us to work more in the field of entomology and to search for other varieties of insects in Lumding. During our present investigation, efforts were made to explore the various types of beetles available in Lumding forest area. Along with identifying the beetle diversity we also tried to measure various bodily features and feeding habits of identified beetle species. About six species of beetles are found as Phylotreta crucifera, Bagrada hillaries, Aristobia reticulator, Callosobruchs maculatus, Henosepilachna vigintioctopunctata, and Sternochotus mangifera. Out of which about $90 \%$ were polyphagous during both larval and adult stages. Majority of the identified species were proven as a threat to agricultural products.
\end{abstract}

KEYWORDS: Beetles, Insecta, Polyphagous, Phytophagus, Lumding \& Coleopteran

Received: Jul 01, 2021; Accepted: Jul 20, 2021; Published: Aug 02, 2021; Paper Id.: IJEEFUSDEC20217

\section{INTRODUCTION}

Insects are considered among the best diversified group of organisms which play many important roles in the ecosystem. In animal kingdom, class insecta of phylum Arthropoda is the most species rich group of organism (Hazarika, and Kalita,2018). The class Insecta dominates every major terrestrial biomass and is responsible for performing many ecological functions (Samways, 2005). Under class insecta, order coleoptera is rich in species and widespread in terrestrial and aquatic environment. Beetles are the group of insects which forms order Coleoptera. There are about 3,50,000 beetles described in reports (New, T., 2007) of which 1,50,000 are found in India (Kazmi and Rammurthi, 2004). These beetles are found in all natural habitats such as vegetative foliage trees and even inside plant like galls, tissue, including dead and decaying ones (Gullon and Crunston, 2010). Some beetles act as pest causing great damage to vegetation whereas some are beneficial as they help in pest control.

In India, about $25 \%$ of beetle species are polyphagous i.e. live on plants. As plants are most essential for all living organisms for their livelihood, so the beetles can categorised as pests (Gilliot, 1995). Beetles feed on plants, breaks down plants and animal matter. On the other hand, some beetles are beneficial as they are able to control population of pest eg. aphids, scale insects, mealy bugs are consumed by ladybird beetle. Similarly, some ground beetles are the common predators of many different insects, caterpillars, wire worms, etc. (Kromp, 1999;). The dung beetles of family scrabacidae help in reducing the population of pestilent flies and parasitic worms as well as functionally are important constituents of terrestrial ecosystem ( Kakkar and Gupta, 2019). 
Assam is enriched with a huge variety of flora and fauna and our current site of survey Lumding forest is heavily decorated with greenery as well as uncountabale number of higher and lower animals. Hence, we decided to explore the different insect populated areas of Lumding and to measure their abundance over there. We also planned to study the bodily features, size, feeding habits, behavioural aspects, economic importance and other special features of the identified beetles and were optimistic to attain some new facts about beetles of Lumding which will motivate other scientists to work further.

\section{MATERIALS AND METHODOLOGY}

\subsection{Study Area}

The rural area of Lumding is located about $3.5 \mathrm{~km}$ from Lumding railway station. It lies in between the geographical location of $25^{\circ} 75^{\prime} \mathrm{N}$ latitude and $93^{\circ} 17^{\prime} \mathrm{E}$ longitude and $125 \mathrm{~m}$ above sea level. The vegetation type found in the area are mixed moist deciduous forest, semi evergreen forest and scattered deciduous forest. Degraded and shrub type of forest are also found here. The village harbors varied natural habitats ranging from grassland, forest and few small and medium sized ponds. The average rainfall is around $2800 \mathrm{~mm}$. The temperature varies from $9^{\circ} \mathrm{c}$ to $19^{\circ} \mathrm{c}$ in winter and $25^{\circ}$ up to $38^{\circ} \mathrm{c}$ in summer and relative humidity ranges from $47 \%$ to $82 \%$. The survey was carried out at four different sites as follows,

- $\quad$ Site 1) Forest area,

- $\quad$ Site 2) Paddy land area,

- $\quad$ Site 3) Vegetable land area, \&

- $\quad$ Site 4) Garden area.

\subsection{Survey Time}

The present study was conducted from March to May 2019. The collection of beetle was executed during morning hours from 6.00 a.m to 11 a.m and evening from $3.30 \mathrm{pm}$ to $6 \mathrm{pm}$.

Various materials like camera, copy, pencil, chloroform containing plastic container, test tubes were taken along during survey. The beetles were collected mainly by handpicking method in test tubes. Butterfly nets were used for catching flying beetles. Some beetles were collected during nighttime with the help of white light source. The collected beetles were kept in chloroform container. The specimen were then photographed using specialised cameras for identification.

\subsection{Identification}

The identification of the species was done with the help taxonomic keys (Hern,1905; Gahen,1996; Jacoby,1998; Mandolik,1996; Cameron, 1930; Maulik,1999, Chandra,2011).

\section{RESULTS AND DISCUSSIONS}

Table 1: Identification of Beetle Species

\begin{tabular}{|c|l|l|l|}
\hline Serial No. & Name of Family & Name of Genus & \multicolumn{1}{|c|}{ Name of Species } \\
\hline 1 & Chrysomelidae & Phyllotreta & Phylotreta crucifera \\
\hline 2 & Pentatomelidae & Bagrada & Bagrada hillaries \\
\hline 3 & Chrysomeliae & Callosobruchus & Callosobruchs maculatus \\
\hline 4 & Cerambicidae & Aristobia & Aristobia reticulator \\
\hline
\end{tabular}




\begin{tabular}{|l|l|l|l|}
\hline \multicolumn{3}{|c|}{ Table 1: Contd,. } \\
\hline 5 & Coccinellidae & Hanosepilachina & Henosepilachna vigintioctopunctata \\
\hline 6 & Curculionidae & Sternochotus & Sternochotus mangifera \\
\hline
\end{tabular}

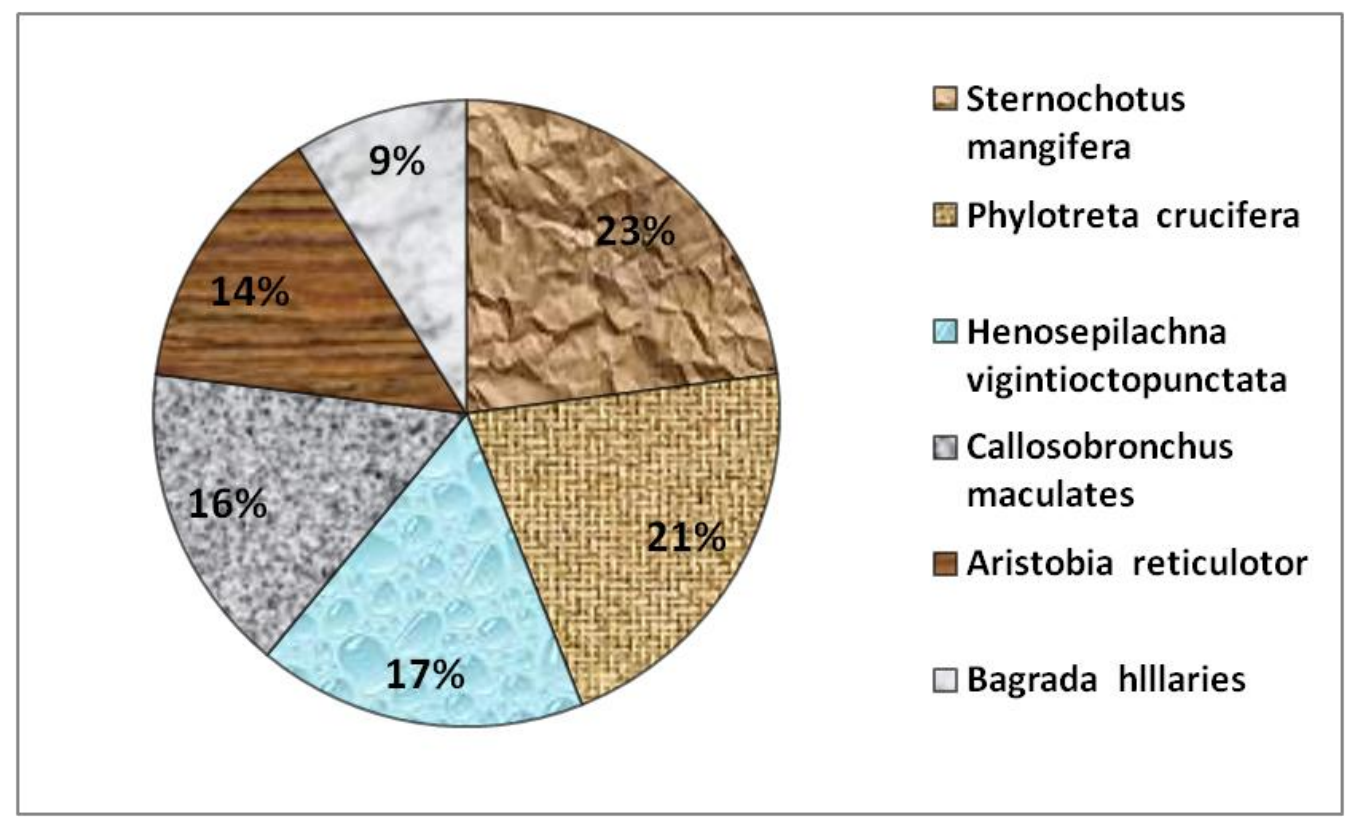

Figure 1: Graphical Representation of Beetle Diversity in Lumding.

Table 2: Identified Beetles with their Feeding Habits

\begin{tabular}{|c|l|l|}
\hline Serial No. & \multicolumn{1}{|c|}{ Name of Species } & Feeding Habits \\
\hline 1 & Phylotreta crucifera & Polyphagous \\
\hline 2 & Bagrada hlllaries & Polyphagous \\
\hline 3 & Callosobronchus maculates & Polyphagous \\
\hline 4 & Aristobia reticulotor & Polyphagous \\
\hline 5 & Henosepilachna vigintioctopunctata & Polyphagous \\
\hline 6 & Sternochotus mangifera & Monophagous \\
\hline
\end{tabular}

Table 3: Comparative Study of Physiological Features of Identified Beetles

\begin{tabular}{|c|l|l|l|l|l|l|}
\hline $\begin{array}{c}\text { Serial } \\
\text { No. }\end{array}$ & Name of Species & $\begin{array}{c}\text { Special } \\
\text { Characteristics }\end{array}$ & $\begin{array}{c}\text { Body } \\
\text { Structure }\end{array}$ & Body Colour & \multicolumn{1}{|c|}{$\begin{array}{c}\text { Host } \\
\text { Plants }\end{array}$} & $\begin{array}{c}\text { Economic } \\
\text { Importance }\end{array}$ \\
\hline 1 & $\begin{array}{l}\text { Phylotreta } \\
\text { crucifera } \\
\text { hind femora }\end{array}$ & $\begin{array}{l}\text { Shiny } \\
\text { blackish with } \\
\text { green blue } \\
\text { hues }\end{array}$ & $\begin{array}{l}\text { Cerious pests } \\
\text { of seedling } \\
\text { causes } \\
\text { Radish } \\
\text { retarded } \\
\text { growth. }\end{array}$ \\
\hline 2 & Bagrada hillaries & $\begin{array}{l}\text { Shield shaped } \\
\text { body }\end{array}$ & $\begin{array}{l}5-7 \mathrm{~m} . \mathrm{m} \\
\text { long }\end{array}$ & $\begin{array}{l}\text { Black with } \\
\text { white \& } \\
\text { orange } \\
\text { marking }\end{array}$ & $\begin{array}{l}\text { Crucifera } \\
\text { crops }\end{array}$ & $\begin{array}{l}\text { Damage } \\
\text { crucifera } \\
\text { crops. }\end{array}$ \\
\hline 3 & $\begin{array}{l}\text { Callosobruchus } \\
\text { maculatus }\end{array}$ & $\begin{array}{l}\text { Grey elytra With } \\
\text { central black spot }\end{array}$ & $\begin{array}{l}3-4.5 \mathrm{~m} . \mathrm{m} \\
\text { long }\end{array}$ & $\begin{array}{l}\text { Reddish } \\
\text { brown with } \\
\text { black spot }\end{array}$ & Beans & $\begin{array}{l}\text { Damage to } \\
\text { lentil, } \\
\text { reduced } \\
\text { germination } \\
\text { capacity. }\end{array}$ \\
\hline
\end{tabular}




\begin{tabular}{|c|l|l|l|l|l|l|}
\hline 4 & $\begin{array}{l}\text { Aristobia } \\
\text { reticulator }\end{array}$ & $\begin{array}{l}\text { Tuft of hair on } \\
\text { apices of } 3^{\text {rd }}, 4^{\text {th }}, \\
\& 5^{\text {th }} \text { segments }\end{array}$ & $\begin{array}{l}20.97- \\
26.34 \mathrm{~m} . \mathrm{m} \\
\text { long }\end{array}$ & $\begin{array}{l}\text { Black body } \\
\text { with white } \\
\text { spot }\end{array}$ & $\begin{array}{l}\text { Litchi \& } \\
\text { Guava }\end{array}$ & $\begin{array}{l}\text { A trunk borer } \\
\text { pest causing } \\
\text { great damage. }\end{array}$ \\
\hline 5 & $\begin{array}{l}\text { Henosepilachna } \\
\text { vigintioctopunctata }\end{array}$ & $\begin{array}{l}\text { Elytra is covered } \\
\text { with } 28 \text { spots }\end{array}$ & $\begin{array}{l}7-10 \mathrm{~m} . \mathrm{m} \\
\text { long }\end{array}$ & $\begin{array}{l}28 \text { black spot } \\
\text { on yellow } \\
\text { elytra }\end{array}$ & $\begin{array}{l}\text { Brinjal, } \\
\text { potato \& } \\
\text { Pumpkin }\end{array}$ & $\begin{array}{l}\text { Great } \\
\text { damage to } \\
\text { family } \\
\text { solanaceae. }\end{array}$ \\
\hline 6 & $\begin{array}{l}\text { Sternochotus } \\
\text { mangifera }\end{array}$ & $\begin{array}{l}\text { Adult press legs } \\
\text { to the body if } \\
\text { disturbed }\end{array}$ & $\begin{array}{l}7.5-9.5 \\
\text { long }\end{array}$ & $\begin{array}{l}\text { Black } \\
\text { grayish or } \\
\text { yellowish } \\
\text { scales }\end{array}$ & Mango seed & $\begin{array}{l}\text { Infect mango } \\
\text { seed causing } \\
\text { threat to } \\
\text { mango } \\
\text { production. }\end{array}$ \\
\hline
\end{tabular}

Our investigation exhibited six species of beetles belonging to six genera and five families. Among these six species, five were polyphagous where as only one is monophagus. Beetles are in general phytophagous \& shows monophagy and oligophagy also(Raju et al., 2016).

The only one monophagous species identified was i.e. Sternochotus mangifera. The families Chrysomelidae, Pentatomelidae, Chrysomeliae, pentatomidae, Cerambicidae, Coccinellidae are polyphagous. The beetle identified under family Curculionidae is monophagous. Insects which are primarily agricultural pests and feed on economically important agricultural and horticultural plants which have wide taxonomic diversity are considered as polyphagous pests. They are harmful to crops prior to their voracious food habits. In the case of polyphagous beetles, there is a lot of scope for adaptation \& survival according to seasonal variation (Slogett \& Magerus, 2000). Though the present study reported different bodily features and feeding habit but extensive study is required on various aspect of beetles such as seasonal variation and inter specific relation among the species.

Monophagous insects are those insects, who feed on only one species of plant. It is to be noted that, the monophagous beetles do not have adaptive benefits due to their restricted feeding to only one plant. In the absence of their particular host plant, they do not survive and finally disappear. The feeding activities of beetles indicate that they have important role in maintaining the balance of ecosystem (Patel, 2015). In this study, highest number of beetle species were found polyphagous which may be prior to the rich vegetation of Lumding Reserve forest. In case of monophagous beetles, there is little or no scope for adaptation and survival in the habitat (Pathania et al., 2015). As the host plants of monophagous beetle ranges from one to few and they are not available in the particular habitat, the beetles are found to leave the habitat in search of food in other places or may have to face death (Koli et al., 2014). But in case of monophagous beetles, there is less scope for adaption and survival in the habitat as they may get certainly one or more host plant at any time of the year in the habitat (Ditchkoff, 2016). Whereas in case of polyphagous beetles, there is a lot of scope for adaptation \& survival due to seasonal variation (Slogott \& Magerus, 2000).

\section{CONCLUSIONS}

Our initiative to explore the beetle abundance in Lumding forest reserve was a noteworthy one as we received healthy varieties of beetle species. Our study also revealed different bodily features and feeding habits but still, we believe that extensive study is required on various aspects of this matter such as seasonal variation and interspecific relation among the species. Hence, we are hopeful that we will get back to this topic once again and will explore new interesting facts about beetles of Lumding. 


\section{REFERENCES}

1. Arnet, R.H., Beetles of the U.S.A manual for identification, American entomological Institute, Amm. Arbour, 2003.

2. Arrow, C.J., The fauna of British India, Ceylon \& Burma, Coleoptera, clavicoma, Taylor \& Francis, Red lion court, Fleet street, London 14-15,1995.

3. Cameron, M.M., The fauna of British India Ceylon \& Burma, staphylimidae. Taylor and Francis, Red Lion Court, Fleet street London, 1930

4. Chandra, k., Insect Diversity of Sikkim, India Pages, 181-206, 2011.

5. Choate, P.M., Manual for identification of the ground beetles (Coleoptera: Carbidae) including tiger beetles of Florida, 2001.

6. Ditchkoff, S., Biodiversity and Ecosystem Management, Oklahoma State University, 12:, 2016.

7. Gahen, C.J., The fauna of Britsh India including Ceylon and Burma coleoptera, Cerambycidae, Taylor \& Francis, 1-329, 1996.

8. Gilliott, S., Entomology- $2^{\text {nd }}$ edition. Springer, Newyork, U.S.A, 1995.

9. Gullan, P.G.\& Crunston, P.S. The Insects- an outline of embryology-4 $4^{\text {th }}$ edition, 2010.

10. Hazarika, H.N. and Kalita, J., “Diversity of Beetles (Insecta: Coleoptera) in Gauhati University Campus, ” Research Journal of Social and Life Sciences, vol. 24, No. 1, 279-284,2018.

11. Horn, W., The fauna of British India including Ceylon and Burma, Coleoptera, Cearambycidae; Taylor \& Francis 1534,1905 .

12. Jacoby, M., The fauna of British India including Ceylon and Burma, Colleoptera, Cerambycidae; vol-1, Taylor \& Francis, 1534, 1998 .

13. Jaworski, T., Hilszce Zanski, J., The effect of temperature and humidity changes on insects development and their impact on forest ecosystems in the context of expected climate change, Forest Research Papers, 74: 345-355, 2013.

14. Kakkar, N. \& Gupta, S. K., Temporal variation on dung beetle,(Coleopteran, scrabicidae) assemblage in Kurakhetra, Hariyana, India.Journal of Thailand Taxa,(9),481-483, 2019.

15. Kazmi \& Ramamurthy, Coleoptera (Insecta) Fauna from Indian Thar Desert, Rajasthan Zoo's print Journal, 19(4), 14471448, 2004.

16. Khaliq A., Javed M., Sohali M., Sagheer M., Environmental effects on insects and their population dynamics, Journal of Entomology and ZoologyStudies, 2:1-7, 2014.

17. Koli, V.K., Bhatnagar, C. and Shekhawat, D.S., Diversity and Species Composition of Odonates in Southern Rajasthan, India, Proc. Zool. Soc., Springer, 2014.

18. Kromp, B., Carrabin beetles in sustainable agriculture- a review on control, efficacy \& cultivation impact \& enhancement agriculture. Ecosystem and Environment. 74(1.3)187-228, 1999.

19. Maulik, S., The fauna of British India, Ceylon \&Burma, Coleoptera Chrysomellidae, 1999.

20. Mandolik, S.,The fauna of British India, Ceylon \&Burma, Coleoptera, Chrysomelidae. Taylor \& Francis, Red Lion, Fleet street. London, 1996.

21. New, T. Components of Beetle species conservation, Beetle in conservation, 137-146, 2007. 
22. Patel, D.R., Diversity and abundance of insect species at Madhya Pradesh forest, International Journal of Multidisciplinary Research and Development, 2(3), 304-307, 2015.

23. Pathania M., Chandel R.S., Verma K.S., Mehta, P.K., Studies on the preliminary ecology of invasive phytophagous Indian Scaraba eidae of North Western Himalaya, Science, Technology and Arts Research Journal, 4:127-138, 2015.

24. Raju, A.J.S., Usha Rani, B., Sulakshana, M., Dilip Kumar, B., Rao, M.M. and Rao, C.P., A Study on morphology\& feeding ecology of Blister Beetles (Mylabris pustlulata) Thurberg (Coleoptera, Meliodae), Advances in pollen Space Research, 34, 127-137, 2016.

25. Samwsays, Insect diversity conservation, Cambridge University Press, Cambridge, 2005.

26. Srivastava Sima, M., Entomofauna associated with bajra crop as observed in an agro-ecosystem in Rajasthan, India, International Journal of Theoritical and Applied Sciences, 4:109-121, 2012.

27. Slogett, j. Magerus, S., Habitat preference and diet in the predatory Coccinellidae (coleopteran) an evolutionary perspective, Biological journal of Lineman society, 70; 63-88, 2000.

28. Kulkarni, N. V., R. Kataria, and S. Gupta. "Evaluation of various oils on Khapra beetle, Trogoderma granarium Everts (Coleoptera: Dermestidae) in terms of survival of adulthood, grain damage and population build-up." Int. J. Agric. Sci. Res 5 : $2250-2257$.

29. Mimoun, K., and S. Doumandji. "Bioecological parameters of the olive beetle Phloeotribus scarabaeoides Bern (Coleoptera, Scolytidae) in an olive grove in Kabylie (Tizi-Ouzou, Algeria)." International Journal of Agricultural Science and Research (IJASR) 4.4: 93-97.

30. Euloge, Faton M. Oscar, et al. "Action of the Combination of Alternaria Alternata and Neochetina Eichhorniae on Growth Parameters of the Water Hyacinth in a Controlled Environment." International Journal of Applied and Natural Sciences (IJANS) 5.4: 9-32.

31. Hashemi, Somayyeh, and Bahram Kazemian. "Dialogical Odes by John Keats: Mythologically Revisited." Theory and Practice in Language Studies (TPLS) 4.8: 1730-1734. 